\title{
Globoid Cell Leukodystrophy: The First Case with Antemortem Diagnosis in Japan
}

\author{
Yoshiro Wada, Tsuneo Arakawa, Nobukazu Chida, \\ Akira Onuma, Hrroshi Nakagawa, Kazuie Iinuma, Yozo \\ Yoshimura, Susumu Nakajima and Yoshiyuki Suzuki* \\ Departments of Pediatrics and Pathology, Tohoku University \\ School of Medicine, Sendai, and Department of Pediatrics,* \\ Faculty of Medicine, University of Tokyo, Tokyo
}

Wada, Y., Arakawa, Ts., Chida, N., Onuma, A. Nakagawa, H., Innuma, K., Yoshmudra, Y., Nakajima, S. and Suzoki, Y. Globoid Cell Leukodystrophy: The First Case with Antemortem Diagnosis in Japan. Tohoku J. exp. Med., 1975, 115 (1), 53-59 — A Japanese boy was diagnosed as globoid cell leukodystrophy on the basis of a marked decrease in the galactocerebroside $\beta$-galactosidase activity in the leukocytes and the serum when one year and two months old. At autopsy when 1 year and 10 months, microscopic findings were characteristic for those of globoid cell leukodystrophy. Galactocerebroside $\beta$-galactosidase activities of leukocytes and sera of his father and mother were found to be half those of control subjects, thus it suggested the parents being heterozygotes of the disease. - globoid cell leukodystrophy; galactocerebroside $\beta$-galactosidase

The present paper deals with the first case of globoid cell leukodystrophy (GLD) in Japan which was diagnosed by the demonstration of a defective activity of galactocerebroside $\beta$-galactosidase in leukocytes and serum obtained from the patient when one year and two months old.

\section{Case Report}

H.S., a one year and two months old Japanese boy was admitted to our clinic in the Tohoku University Hospital with a complaint of mental and physical deterioration.

The parents were not consanguineous, but the grandmother and great-grandfather on the maternal side were related. One of his aunts on the maternal side was mentally retarded and had frequent attacks of generalized tonic convulsions and died at the age of 11 years. An elder brother of the patient suddenly died of unknown origin on 2 days of life.

The proband was born on Jan. 17, 1971, after a full-term pregnancy and an uneventful delivery. His birth-weight and height were $4,150 \mathrm{~g}$ and $54 \mathrm{~cm}$, respectively. The circumferences of the chest and the head were 36 and $35.5 \mathrm{~cm}$, respectively.

Received for publication, November 14, 1974. 
There was no abnormality in his neonatal history. His progress had been entirely normal until 6 months of age, when difficulty in feeding developed. At that time his parents noticed that he became lean and weak to cry, and that his limbs were becoming progressively more "stiff".

Thereafter he showed an apathetic face and seemed to be indifferent to the surroundings.

An electroencephalogram, taken at the age of 7 months, suggested the presence of diffuse organic brain damage.

Since 11 months of age, he repeatedly suffered from episodic attacks of vomiting (probably due to acetonemic vomiting).

On the admission, when 1 year and 2 months old, he was extremely emaciated. His weight and height were $5.9 \mathrm{~kg}$ (normal $9.1 \mathrm{~kg}$ ) and $69.5 \mathrm{~cm}$ (normal $74.1 \mathrm{~cm}$ ), respectively. His extremities were of marked rigidity, with scissoring of his legs. His arms were flexed at the elbow with clenching fists. He could not hold his head up nor roll over himself. An only emotional expression observed was to cry weakly when some mechanical stimulation was given on his body.

His hair and eyes were black in color. The palate was high-arched and narrow. There was no lymphadenopathy. The anterior fontanel measured $1.5 \mathrm{~cm} \times 1.5$ $\mathrm{cm}$ and was flat. There was no deformity in the skeletal systems including skull.

The heart and lungs were clear to auscultation. Abdomen was soft and flat. The liver and spleen were not palpable.

Deep tendon reflexes were not exaggerated, but Oppenheim's, Chaddock's and Babinski's reflexes were positive, while both nuchal rigidity and Kernig's sign were negative.

Laboratory data. Routine examinations of the urine and feces revealed no abnormality. The peripheral blood and bone marrow pictures showed no abnormality. The following laboratory tests gave normal findings: liver function tests, serum lipids, serum protein and its fraction, serum mucoprotein, blood ammonia nitrogen, serum electrolytes, blood sugar, serum acid and alkaline phosphatase activities, serum creatine phosphokinase, lactic dehydrogenase, urea nitrogen, serum amino acids, serum folic acid, non-volatile organic acids and amino acids in the urine and cerebrospinal fluid.

But protein content of the cerebrospinal fluid was found to be increased, being $230 \mathrm{mg}$ per $100 \mathrm{ml}$.

Results of blood gas analysis were normal. Chromosomes were also normal in number as well as configuration.

There was a prolongation of PR interval in his electrocardiogram, but cardiomegaly was not observed in his X-ray film.

$\mathrm{X}$-ray films of the bone revealed severe osteoporosis of the whole skeletal system, without any delay of the bone age.

Funduscopy revealed a marked optic atrophy and irregular reflexes on the retina bilaterally, but no cherry-red spots.

Clinical course. Within a few months after the admission, his extremities 
became hypotonic. Since 1 year and 7 months of life, he was fed by tube-feeding, but he regurgitated frequently. He died on Nov. 11, 1972, when 1 year and 10 months old.

\section{Special Studies}

\section{Methods}

$\mathrm{N}$ - $\beta$-Acetylglucosaminidase activity in serum was assayed by 0 'Brien et al.'s method (1970).

Serum and leukocyte galactocerebroside $\beta$-galactosidase activities were assayed by means of Bowen and Radin's method (1969), with minor modifications (Suzuki and Suzuki 1971).

Uric acid levels in plasma, urine and cerebrospinal fluid were determined by Henry et al.'s method (1957). Phosphoribosyltransferase activities were assayed by Kelley et al.'s method (1967).

\section{Results}

Phospholipids in the erythrocytes $(2.0 \mathrm{mg} / \mathrm{ml}$ packed erythrocytes $)$ and

TABLE 1. Galactocerebroside $\beta$-galactosidase activity in leukocytes

\begin{tabular}{|c|c|}
\hline & $\begin{array}{c}\text { Galactocerebroside } \beta \text {-galacto- } \\
\text { sidase activity } \\
\text { (nmoles/mg protein } / \mathrm{hr} \text { ) }\end{array}$ \\
\hline \multicolumn{2}{|l|}{ Our own patient (H.S.) } \\
\hline (1y. $5 \mathrm{~m} .5)$ & 0.06 \\
\hline \multicolumn{2}{|l|}{ His father } \\
\hline$(35 \mathrm{y} \cdot \delta)$ & 0.66 \\
\hline \multicolumn{2}{|l|}{ His mother } \\
\hline (25y.우) & 0.58 \\
\hline \multicolumn{2}{|l|}{ Control } \\
\hline T.T. (1y. $11 \mathrm{~m} .5)$ & 1.69 \\
\hline M.S. (3y. $8 \mathrm{~m}$. 우) & 1.35 \\
\hline Adult $\quad 1$ & 1.49 \\
\hline Adult & 1.11 \\
\hline
\end{tabular}

TABLE 2. Galactocerebroside $\beta$-galactosidase activity in the serum

Galactocerebroside $\beta$-galactosidase activity (nmoles/hr/l00 ml)

Our own patient (H.S.)

(1y. 5m. of) 1.1

His father (35y. §) 3.4

His mother

(25y. 우) $\quad 5.7$

Controls

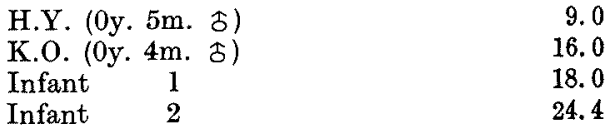


TABLE 3. Phosphoribosyltransferase (PRT) activity in erythrocytes

\begin{tabular}{cccc}
\hline & Adenine-PRT & Guanine-PRT & Hypoxanthine-PRT \\
\hline $\begin{array}{c}\text { Our own patient (H.S.) } \\
\text { (1y. 5m. \$ })\end{array}$ & 30.3 & & \\
Mean \pm S.D. & $29.1 \pm 6.8$ & 104.2 & $103.9 \pm 20.7$ \\
(Number of cases) & $(93)$ & $(93)$ & $100.5 \pm 21.6$ \\
\end{tabular}

Activities are given in nmoles/mg protein/hr

TABLE 4. Results of chemical analysis of the cerebrospinal fluid of our patient (H.S., 1y.2m. ô)

\begin{tabular}{ll}
\hline Cell count & $8 / 3$ \\
Protein & $230 \mathrm{mg} / 100 \mathrm{ml}$ \\
Uric acid* & $1.0 \mathrm{mg} / 100 \mathrm{ml}$ \\
Sugar & $58 \mathrm{mg} / 100 \mathrm{ml}$ \\
Chloride & $123 \mathrm{mEq} /$ liter \\
GOT & $14($ R.F.) \\
GPT & 3 (R.F.) \\
LDH & 75 \\
\hline
\end{tabular}

* (normal range $0.15-0.3 \mathrm{mg} / 100 \mathrm{ml}$ )

urinary sulfatides were found to be within normal ranges.

The galactocerebroside $\beta$-galactosidase activity of the patient was found to be markedly decreased in both leukocytes and serum, and that the enzyme activity in both leukocytes and sera obtained from the parents was found to be about half that of control subjects (Tables 1 and 2).

Uric acid levels in the plasma and urine from the patient were $2.8 \mathrm{mg} / 100$ $\mathrm{ml}$ and $140.8 \mathrm{mg} /$ day, respectively. Phosphoribosyltransferase activities in the erythrocytes were found to be within normal limits (Table 3). But uric acid in the cerebrospinal fluid of our patient was $1.0 \mathrm{mg} / 100 \mathrm{ml}$, which was remarkably increased as compared with the normal range (Table 4).

\section{Autopsy Findings}

\section{Macroscopic findings}

The brain was small in size, weighing $580 \mathrm{~g}$. Frontal area of the cerebrum appeared extraordinarily narrow in shape. Gyli were shrunken and sulci were widened.

On the frontal section, the white matter appeared remarkably atrophic, while the gray matter was not so, and a plenty of small cysts were seen in the bulk (Figs. 1 and 2).

The cerebellum was also small, the weight of the cerebellum with brain stem being $75 \mathrm{~g}$.

The spinal cord was also thin and wax-colored.

There were multiple necroses of millet-seed size in both lungs, which were diffusely edematous. 


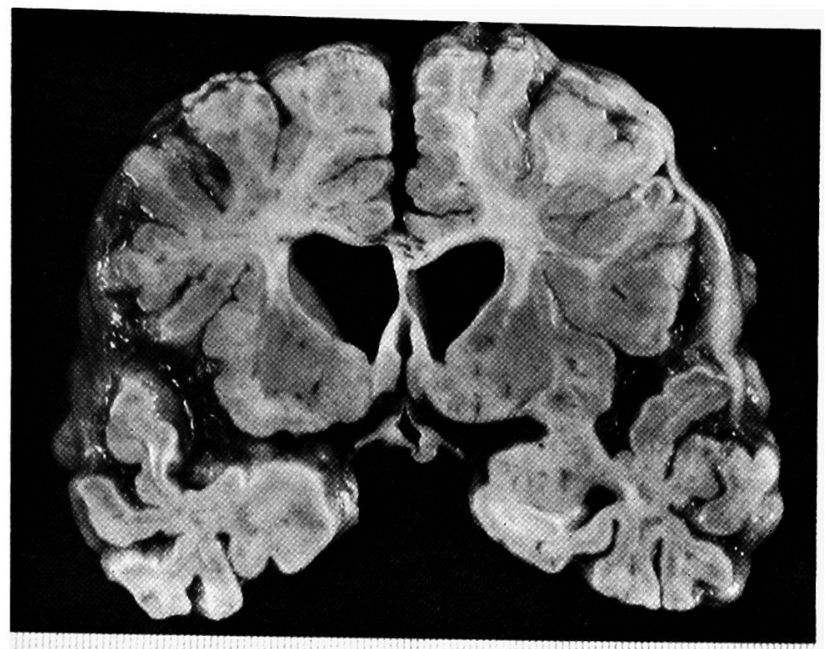

Fig. 1. Remarkable atrophy of the white matter of the brain of our patient (H.S.).

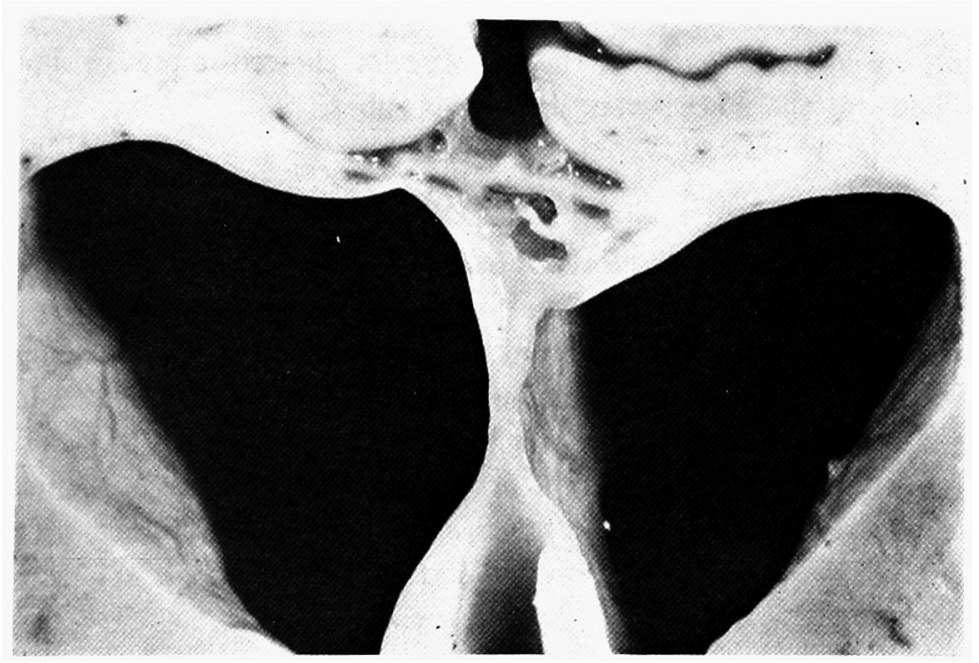

Fig. 2. Small cysts in the bulk of the brain of our patient (H.S.).

The liver was uniformly fatty.

\section{Microscopic findings}

In the white matter of the cerebrum, oligodendroglia decreased in number and plenty of epitheloid cells and globoid bodies were found (Fig. 3).

There were diffuse demyelination and gliosis as well as loss of ganglion cells especially in nucleus olivaris, nucleus pontis and nucleus dentatus. Perivascular lymphocytic infiltration was found in the cerebral cortex and its bundles.

In some place of the deep white matter, there were cystic structures especially 


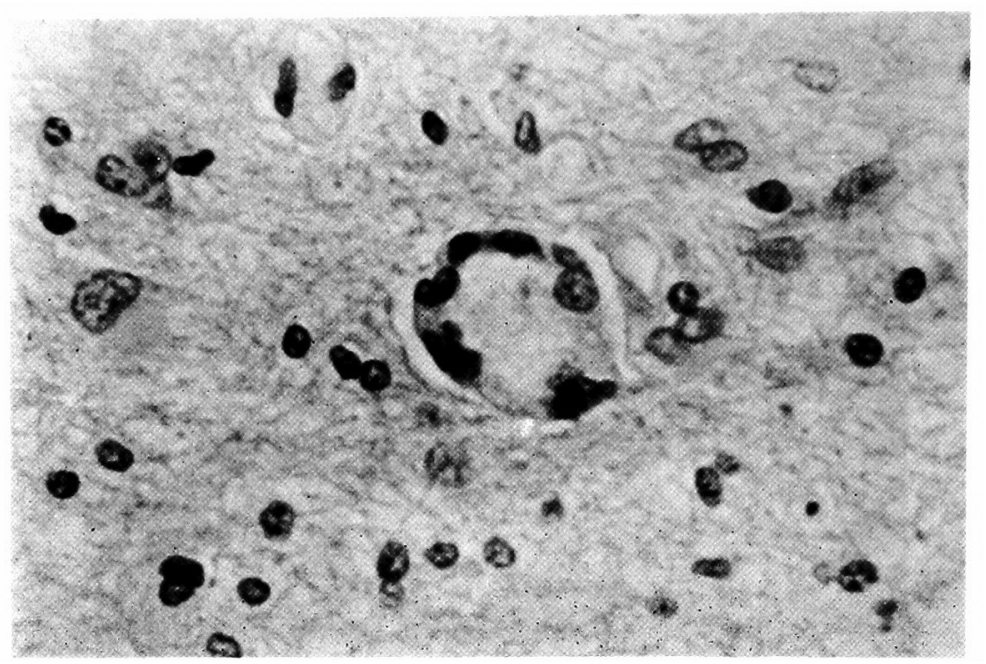

Fig. 3. Typical globoid body seen in the white matter of the brain of our patient (H.S.).

in the perivascular areas.

In the gray matter, most of the nerve cells showed more or less necrotic changes, which was the most severe in nucleus ruber.

\section{Discussion}

Defective activity of galactocerebroside $\beta$-galactosidase in GLD was first reported by Suzuki and Suzuki (1970).

The cases with antemortem diagnosis of this disorder by the demonstration of the defective activity of the enzyme in leukocytes and/or serum have been reported in 9 cases up to date (Suzuki and Suzuki 1971; Young et al. 1972; Suzuki 1973).

The present report of ours was the first case with antemortem diagnosis of this disorder in Japan, in which autopsy confirmed microscopic findings of the brain characteristic for this illness (Andrews et al. 1971; Jacob et al. 1973; Norman et al. 1973).

An abnormally high concentration of uric acid was found in the cerebrospinal fluid of our patient, but its significance remains obscure. Uric acid levels in the serum and urine were found to be within normal ranges and hypoxanthineguanine phosphoribosyltransferase activity of erythrocytes was also normal in our patient.

\section{References}

1) Andrews, J.M., Cancilla, P.A., Grippo, J. \& Menkes, J.H. (1971) Globoid cell leukodystrophy (Krabbe's disease): Morphological and biochemical studies. Neurology, 21, 337-352.

2) Bowen, D.M. \& Radin, N.S. (1969) Cerebroside galactosidase: A method for determination and a comparison with other lysosomal enzymes in developing rat brain. J. Neurochem., 16, 501-511. 
3) Henry, R.J., Sobel, C. \& Kim, J. (1957) A modified carbonate-phosphotungstate method for the determination of uric acid and comparison with the spectrophotometric uricase method. Amer. J. clin. Pathol., 28, 152-160.

4) Jacob, J.C., Kuthy, K.M., Islam, M., Dominic, R.G. \& Dawson, G. (1973) Krabbe's disease: globoid cell leukodystrophy. Canad. med. Ass. J., 108, 1398-1400.

5) Kelley, W.N., Rosenbloom, F.M., Henderson, J.F. \& Seegmiller, J.E. (1967) A specific enzyme defect in gout associated with overproduction of uric acid. Proc. nat. Acad. Sci. (Wash.), 57, 1735-1739.

6) Norman, M.G., Grans, M.H. \& Lowden, J.A. (1973) Failure to thrive and spasticity in a 5-month-old girl. J. Pedixt., 83, 1078-1082.

7) O'Brien, J.S., Okada, S., Chen, A. \& Fillerup, D.L. (1970) Tay-sachs disease detection of heterozygotes and homozygotes by serum hexosaminidase assay. New Eng. J. Med., 283, 15-20.

8) Suzuki, K. \& Suzuki, Y. (1970) Globoid cell leukodystrophy (Krabbe's disease): deficiency of galactocerebroside $\beta$-galactosidase. Proc. nat. Acad. Sci. (Wash.), 66, 302-309.

9) Suzuki, Y. (1973) Krabbe's disease (globoid cell leukodystrophy). Brain \& Nerve (Jap.), 25, 1259-1262.

10) Suzuki, Y. \& Suzuki, K. (1971) Krabbe's globoid cell leukodystrophy: Deficiency of galactocerebrosidase in serum, leukocytes, and fibroblasts. Science, 171, 73-75.

11) Young, E., Wilson, J., Patrick, A.D. \& Crome, L. (1972) Galactocerebrosidase deficiency in globoid cell leukodystrophy of late onset. Arch. Dis. Childh., 47, 449-450. 